\title{
BREAD OF LIFE
}

Home truths.

\section{BY BETH CATO}

$\mathrm{I}$ t was dangerous - traitorous - for people to speak aloud of their memories of Earth. It meant they risked giving the Dendul exactly what they wanted. And yet, people often couldn't help but dismiss that peril when they entered Sonya's Earth Bread Shop.

Sonya looked up as a man entered her business. He was the typical sort. In his forties or fifties, his hair silver; not that different from her, gender aside. Both of them old enough to remember Earth in its glory. $\mathrm{He}$ paused at the door and breathed in. Grief flashed across his face.

"My god," he whispered.

"You must be Franklin with the order for rye. Your ship docked right on time."

Humanity had scattered across a dozen systems, yet Sonya didn't have to advertise her wares. Word managed to spread among any human crew members on the freighters and shuttles that passed through Kaji Station. Most ordered ahead to get what they wanted, but she always kept favourites on display. Bread rarely went to waste.

A thin visor wrapped around Franklin's eyes like a clear halo and did nothing to hide his dazed expression. "This place - how do you even get the ingredients?" He had a trim body like most deep spacers, as they relied on strict calorie packets when in transit.

"It's expensive. I don't make much profit." That was the truth. "I source my wheat and everything else through legitimate traders who specialize in human palatable foods. I beamed you that info when you ordered."

Sonya pulled out a bundle wrapped in white parchment. The paper was folded just so, as if she had swaddled a newborn baby.

"I read it. Maybe it seems too good to believe." He stared at the goods preserved beneath the counter's dome. "You have sourdough available in slices? And challah?" He leaned against the glass as if suddenly boneless.

Sonya stared at him, waiting.

"My grandmother. She used to make challah for holidays." He said it in the lowest discernible whisper. "This big braided round. She insisted it had to be done by hand, that it tasted best. The smell, when that loaf would come out of the oven." He inhaled, his breath rattling with checked emotion. "It even smells right here. I had forgotten. It's been so long since..."

The Dendul had obliterated Earth.

To them, humans radiated potent emotions in a way unlike any other species. Spoken memories, in particular, exuded deep flavours that the Dendul absorbed to ascend into a state of blissful intoxication. When they scorched Earth, their intent wasn't to slaughter the majority of humanity. No, they ripened memories for harvest.

"Most every culture on Earth had some kind of bread," said Sonya. "I make it all. I hear it all. I think almost everyone had a grandmother who baked. I even have people who come to me for those old commercial sliced breads."

He laughed, high and giddy. "The stuff in every kid's lunch box, with peanut butter and jelly, or that god-awful bologna. Even that sounds good these days. This challah in here? How much - " He blinked as she beamed the new total to his visor. The non-vocal response $\rightarrow$ NATURE.COM @NatureFutures $f$ go.nature.com/mtoodm
Follow Futures: was habit for Sonya; the Kaji regarded the mention of money as crude. "I'll take the rest of that loaf.
There's a woman on my crew .. this will mean a lot to her."

Sonya wrapped it up. "Thanks for beaming your payment promptly."

He nodded as she passed the bagged bread to him. "Yeah. Yeah. You do this ... why? Doesn't it drive you crazy to remember what we lost, every day?"

"It would drive me crazier not to."

He backed away, his gaze distant, and said nothing as he departed.

Sonya looked up at the obscured sensors that recorded their conversation at much deeper levels than mere vocalization. A human with synaesthesia might hear music and see colours; for the Dendul, Franklin's brief, emotional story would evoke catatonic ecstasy.

The Dendul had tried torturing humans to force out memories, but physical pain tainted the results. Made them bitter. Alcohol also changed the flavour in a distasteful way. The words had to be provoked in an unimpaired, natural way.

Many Earth foods proved to be good bait, but nothing was as powerful and universal as bread.

Sonya reached into the flash freezer for another loaf of challah for the dome, and to ready her next orders for the day. Portuguese sweet bread. Pitta. Ciabatta. She breathed in the redolent, yeasty smell.

This memory trap was for her own selfish needs, too. To draw in the few humans who came to this far station, to hear them whisper history as a conspiracy. She drank it in. Savoured it. As if she still ran the counter at her father's bakery in Denver. As if she wasn't on a revolving rod in deep space, a speck in a diaspora of a million remaining human souls.

The door chimed and a white-haired woman entered. "There really is a bakery on this station! The smell here. It reminds me..." She drew silent, her expression pained.

Sonya said nothing. She waited. The stories would come. .

Beth Cato resides in Arizona. She is the author of the Clockwork Dagger steampunk fantasy series from Harper Voyager. Her website is BethCato.com. 